\title{
The alpha-fetoprotein serum is still reliable as a biomarker for the surveillance of hepatocellular carcinoma in Indonesia
}

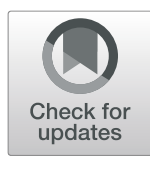

\author{
Chyntia Olivia Maurine Jasirwan ${ }^{1 *} \mathbb{D}$, Alessa Fahira ${ }^{2}$ Lianda Siregar $^{3}$ and Imelda Loho ${ }^{3}$
}

\begin{abstract}
Background and aims: Hepatocellular carcinoma (HCC), the most common type of liver cancer, is one of the leading causes of cancer-related death worldwide with an inferior prognosis. In Indonesia, the average life expectancy is less than 5 months, with most patients being in an advanced stage wherein the survival rate is very low. Early detection through surveillance program is very crucial. HCC guidelines worldwide have provided surveillance recommendation through the examination of a-fetoprotein (AFP) and ultrasound for patients at risk in developing HCC. However, there have been some controversies regarding the usage of AFP concerning its low sensitivity and specificity in detecting HCC. Therefore, the effectiveness of AFP in the surveillance of HCC patients and identifying the parameters most associated with the increase of AFP $\geq 10 \mathrm{ng} / \mathrm{ml}$ in Indonesia should be evaluated.
\end{abstract}

Methods: We analyzed medical records of HCC patients and those at high risk of developing HCC through crosssectional study, including patients with cirrhosis and hepatitis B and C, from 2015 to 2017 who underwent treatment at the Cipto Mangunkusumo National General Hospital and Dharmais National Cancer Hospital, Indonesia.

Results: The sensitivity and specificity of AFP in the surveillance of HCC in Indonesia with a cut-off of $10 \mathrm{ng} / \mathrm{ml}$ were 82.6 and $71.2 \%$, respectively. The parameters most associated with the increase of AFP $\geq 10 \mathrm{ng} / \mathrm{ml}$ according to multivariate analysis were the etiology of hepatitis B, the stage of Barcelona Clinic Liver Cancer (BCLC) B and C, and the presence of cirrhosis, respectively.

Conclusion: AFP can still be used in the surveillance of HCC in Indonesia for its high sensitivity value.

Keywords: a-Fetoprotein, Hepatocellular carcinoma, Surveillance, Biomarker

\footnotetext{
* Correspondence: chynmadu@gmail.com;

hepatologibilierfkuirscm@gmail.com

${ }^{1}$ Hepatobiliary Division, Department of Internal Medicine, Faculty of

Medicine, Universitas Indonesia, Cipto Mangunkusumo National General

Hospital, Jakarta, Indonesia

Full list of author information is available at the end of the article
}

(c) The Author(s). 2020 Open Access This article is licensed under a Creative Commons Attribution 4.0 International License, which permits use, sharing, adaptation, distribution and reproduction in any medium or format, as long as you give appropriate credit to the original author(s) and the source, provide a link to the Creative Commons licence, and indicate if changes were made. The images or other third party material in this article are included in the article's Creative Commons licence, unless indicated otherwise in a credit line to the material. If material is not included in the article's Creative Commons licence and your intended use is not permitted by statutory regulation or exceeds the permitted use, you will need to obtain permission directly from the copyright holder. To view a copy of this licence, visit http://creativecommons.org/licenses/by/4.0/ The Creative Commons Public Domain Dedication waiver (http://creativecommons.org/publicdomain/zero/1.0/) applies to the data made available in this article, unless otherwise stated in a credit line to the data. 


\section{Background}

Liver cancer is known to be a significant cause of cancerdeath worldwide-owing to the death of 800.000 patients each year [1]. Ninety percent of all liver cancer cases in the world are in the form of hepatocellular carcinoma (HCC), making it the most common form of liver cancer [2]. HCC is a significant health problem worldwide because of the constant risk of its known etiologies, including hepatitis $B$ (especially in developing countries), hepatitis $\mathrm{C}$, and the alarming increase of metabolic syndrome cases such as obesity and high alcohol consumption-both of which correlate with the increasing incidence of fatty liver disease.

Furthermore, HCC is regarded as deadly due to its poor prognosis. In Indonesia, the median for the survival of HCC patients in the period from 1998 to 1999 was 138 days, and in the period from 2013 to 2014 was 146 [3] - showing that patients would, in average, only have less than 5 months life expectancy which also shows a very low improvement of survival despite being 15 years apart. This happens because of the patient's tendency to seek treatment only reaching the advanced stage, wherein the survival of patients with HCC is very low. Thus, early detection through HCC surveillance program is believed to be an indisputable strategy to prevent the patient is coming at an advanced stage [4].

A surveillance method that has been widely recommended in several guidelines globally utilizes $\alpha$-fetoprotein (AFP) biomarker and abdominal ultrasonography [5, 6]. In the Cipto Mangunkusumo National General Hospital (RSCM), the surveillance of HCC is routinely held every 6 months for patients at risk of developing HCC. Surveillance of $\mathrm{HCC}$ is conducted by examining the liver using USG and measuring AFP in blood. The cut-off used in Indonesia and many other countries is $10 \mathrm{ng} / \mathrm{ml}$ or if there is an elevation of AFP levels compared with the previous examination. Patients who are suspected of having HCC are further diagnosed [7]. However, in recent years, there have been studies showing controversies regarding the use of AFP in clinical settings-because of the low sensitivity and specificity of AFP when used to screen HCC [8]. It has been stated in some studies that patients with HCC may not experience any elevation of AFP at all. Conversely, patients who were not diagnosed with $\mathrm{HCC}$ but were diagnosed with cirrhosis, cholangiocarcinoma or other tumours were found to have elevated AFP [9-12]. Recommendation regarding the use of AFP for HCC screening was thus excluded from the American Association for the Study of Liver Diseases guideline in the year 2010 [13]. AFP was also regarded as neither being sensitive nor specific for use as a diagnostic tool in the guideline published by European Association for the Study of the Liver in the year of 2012 [14]. Nevertheless, some countries in Asia still recommend the use of AFP along with USG for the screening of HCC in the guideline published by Asian Pacific Association for the Study of the
Liver in the year 2010 [15], and the guideline published by China (2011) [16] and Japan (2013) [17].

There have been no previous studies that evaluate the use of AFP in the surveillance of HCC in the Indonesian population. Therefore, this study tried to assess the sensitivity and specificity of AFP in Indonesia, where the population includes patients who undergo treatment in the Cipto Mangunkusumo National General Hospital and Dharmais National Cancer Hospital, Indonesia.

\section{Methods}

\section{Study design and population}

This cross-sectional study was conducted using the HCCbased registry from 2015 to 2017. HCC registry of Indonesia is a database developed by the Indonesian Liver Cancer Study Group and Bayer Group which meant to record all HCC patient's medical data in Indonesia. Currently, two centers have been enrolled in this registry of which include RSCM and RSKD. Other registries (i.e. hepatitis and cirrhosis registry of Indonesia) have been developed earlier. Enroll criteria are all patients diagnosed with HCC in both RSCM and RSKD. Data are collected by clinicians who provided care to the patient and are processed by the research assistant of the Hepatobiliary Division. All RSCM and RSKD patients high-risk of HCC (which include having hepatitis $\mathrm{B}$, hepatitis $\mathrm{C}$ and/or cirrhosis), which are not identified as having HCC, are enrolled either in the hepatitis registry and cirrhosis registry. The diagnosis of HCC in RSCM and Dharmais National Cancer Hospital, Jakarta (RSKD), was made from patients with positive surveillance results of either elevated AFP $\geq 10 \mathrm{ng} / \mathrm{ml}$ or positive ultrasound, which are then confirmed by a single examination of triple-phase abdominal CT scan. If nodules were found but are not typical for HCC, we will then proceed with Primovist-enhanced magnetic resonance imaging (MRI). In some cases, HCC was confirmed by histological examination. Etiologies of HCC included in this study were separated into viral (hepatitis $\mathrm{B}$ and hepatitis $\mathrm{C}$, or both) and non-viral (non-hepatitis B and C). Hepatitis B and C serology markers were examined. Hepatitis B was detected through the presence of hepatitis $\mathrm{B}$ surface antigen and hepatitis $B$ virus (HBV) DNA, while hepatitis $C$ was detected through the presence of hepatitis $\mathrm{C}$ virus $(\mathrm{HCV})$ antibody and HCV RNA. The presence of cirrhosis in patients was evaluated through clinical symptoms, abdominal ultrasonography, and transient elastography.

\section{Data collection}

All patients with HCC diagnosed in RSCM and RSKD between July 2015 and June 2017, whose data were recorded in the HCC registry, were analyzed (Fig. 1). Patients included in this study were HCC patients $(n=132)$ and highrisk populations including patients with cirrhosis $(n=66)$, hepatitis B patients with the absence of cirrhosis $(n=66)$, 


\section{HCC patients selection}

\begin{tabular}{|c|c|c|c|}
\hline \multirow{2}{*}{$\begin{array}{l}154 \text { selected patients data } \\
\text { in the registry of RSCM }\end{array}$} & \multirow{2}{*}{$\begin{array}{l}5 \text { data were excluded due } \\
\text { to incomplete data }\end{array}$} & $\begin{array}{l}\text { computer } \\
\text { generated }\end{array}$ & $66 \mathrm{HCC}$ \\
\hline & & randomization & patients selected \\
\hline 112 selected patients data & 10 data were excluded due & $\begin{array}{l}\text { computer } \\
\text { generated }\end{array}$ & $66 \mathrm{HCC}$ \\
\hline in the registry of RSKD & to incomplete data & randomization & patients selected \\
\hline
\end{tabular}

\section{Cirrhosis patients selection}
156 selected patients data
73 data were excluded due
computer
in the registry of RSCM
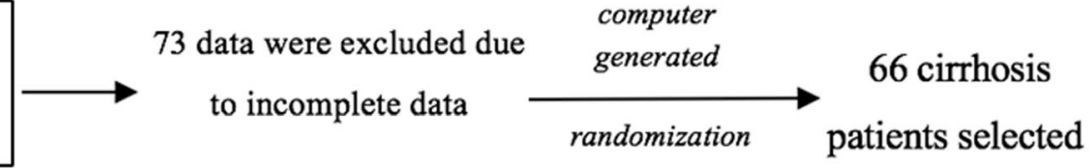

\section{Hepatitis B patients selection}

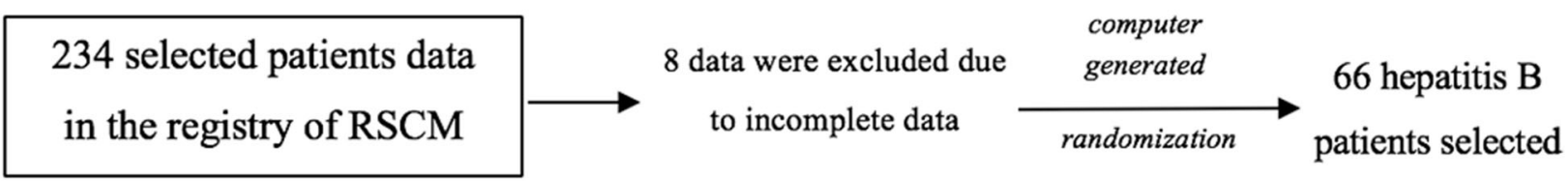

\section{Hepatitis C patients selection}

\section{5 selected patients data in the registry of RSCM \\ No data were excluded

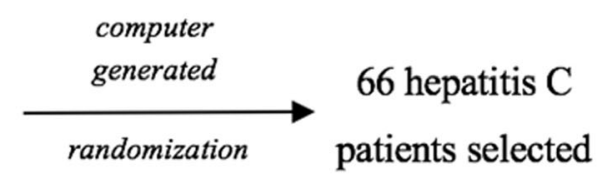

Fig. 1 The selection process of subjects in each category. Subjects were first selected by excluding duplicates (not shown in the figure) and continued with the exclusion of incomplete data

and hepatitis $C$ patients with the absence of cirrhosis $(n=$ 66). Patients with other malignancies were excluded from this study. This research was conducted in the Hepatobiliary Division, Cipto Mangunkusumo National General Hospital. Subjects were selected by computer-based randomized sampling using the SPSS application from the existing registry. The independent variable of this study was the AFP level below and above the cut-off of $10 \mathrm{ng} / \mathrm{ml}$ with 10 dependent variables including age, sex, etiology of $\mathrm{HCC}$, number of nodules, nodule size, cirrhosis, portal venous thrombus, metastasis, Child-Pugh score and the staging of BCLC.

\section{Statistical analysis}

Data processing was carried out using the IBM Statistical Package for the Social Sciences software version 21 for Mac, which included the (1) calculation of the AFP tests and gold standards to obtain sensitivity and specificity and (2) exploration of factors that might affect AFP levels in HCC patients through bivariate and multivariate analysis. The categorical variables were compared by using the chi-square test, Fisher's test or Mann-Whitney test, if appropriate. Variables with a value of $P \leq 0.25$ in bivariate analysis were included in multivariate logistic regression analysis. 


\section{Ethics approval}

This study was approved by the ethics committee of The Faculty of Medicine, University of Indonesia with the letter number of 0514/UN2.F1/ETIK/2018.

\section{Results}

This study included 132 HCC patients and 198 patients at risk in developing HCC (66 cirrhotic patients, 66 noncirrhotic hepatitis B patients, and 66 non-cirrhotic hepatitis $\mathrm{C}$ patients). The characteristic of HCC patients is portrayed in Table 1 and the AFP distribution in HCC patients and control is shown in Fig. 2. AFP levels above $10 \mathrm{ng} / \mathrm{ml}$ were seen in $82.6 \%$ (109 of 132 patients) HCC patients and $29 \%(57 / 198)$ non-HCC patients. In this study, all HCC patients with elevated AFP $\geq 10 \mathrm{ng} / \mathrm{ml}$ were found to have positive nodule (either single or multiple nodules) on ultrasound. However, 23 (17\%) HCC patients with positive nodule on ultrasound were found to have normal AFP. The result of this study shown the sensitivity levels of $82.6 \%$, specificity levels of $71.2 \%$, the positive predictive value of $65.6 \%$, the negative predictive value of $85.9 \%$ and the positive likelihood ratio of 2.87 . False positive from all patients with AFP above $10 \mathrm{ng} / \mathrm{ml}$ was 34\% (57/ 166) (Table 2).

Bivariate analysis, shown in Table 3, revealed a significant relationship between AFP levels above or below 10 $\mathrm{ng} / \mathrm{ml}$ and the etiology of HCC $(p=0.011)$ and cirrhosis $(p=0.016)$, yet we found no significant association with other variables. Multivariate analysis, portrayed in Table 4, revealed the parameter most associated with the risk of having an AFP level above $10 \mathrm{ng} / \mathrm{ml}$ was patients within the stage $\mathrm{C}$ of $\mathrm{BCLC}(\mathrm{OR}=16 ; p=0.002)$, followed by patients the HCC etiology of hepatitis $\mathrm{B}(\mathrm{OR}=6.35 ; p=$ $0.005)$, cirrhosis $(\mathrm{OR}=4.31 ; p=0.016)$, and within the stage $\mathrm{B}$ of $\mathrm{BCLC}(\mathrm{OR}=5.99 ; p=0.019)$, respectively.

\section{Discussion}

The population of patients at risk of developing HCC will undergo surveillance through the measurement of AFP levels and evaluation of the liver by ultrasound every 6 months. The population at risk includes patients with liver cirrhosis of any etiology and hepatitis B patients. In the Indonesian National Consensus of the Management of Hepatocellular Carcinoma [7] population at risk in developing HCC also includes chronic hepatitis $\mathrm{C}$ patients who developed fibrosis, but this population of patients has not yet been included in the current surveillance program in clinical practice. The cut-off of $10 \mathrm{ng} / \mathrm{ml}$ in the surveillance of HCC is deemed most appropriate as it yields high sensitivity. Although cut-off of $16-20 \mathrm{ng} / \mathrm{ml}$ resulted in higher specificity of $90 \%$, the sensitivity would only reach $60 \%$-hence $40 \%$ of HCC cases would be missed [18]. On the other hand, the cut-off of $10 \mathrm{ng} / \mathrm{ml}$ would reach a higher sensitivity. According to Chan SL, et al. [19] in
Table 1 Hepatocellular carcinoma patient's characteristic

\begin{tabular}{|c|c|}
\hline Variable & No. of Patients (\%) \\
\hline \multicolumn{2}{|l|}{ Age } \\
\hline$<40$ years old $(n=12)$ & $9.1 \%$ \\
\hline $40-<50$ years old $(n=71)$ & $53.8 \%$ \\
\hline$\geq 50$ years old $(n=49)$ & $37.1 \%$ \\
\hline \multicolumn{2}{|l|}{ Sex } \\
\hline Male $(n=94)$ & $71.2 \%$ \\
\hline Female $(n=38)$ & $28.8 \%$ \\
\hline \multicolumn{2}{|l|}{ Etiology of HCC } \\
\hline Hepatitis B $(n=84)$ & $63.6 \%$ \\
\hline Hepatitis C $(n=22)$ & $16.7 \%$ \\
\hline Non-Hepatitis B and Non-C $(n=18)$ & $13.6 \%$ \\
\hline Hepatitis B and Hepatitis C $(n=8)$ & $6.1 \%$ \\
\hline \multicolumn{2}{|l|}{ Cirrhosis } \\
\hline No $(n=59)$ & $44.7 \%$ \\
\hline Yes $(n=73)$ & $55.3 \%$ \\
\hline \multicolumn{2}{|l|}{ BCLC staging } \\
\hline $\mathrm{A}(n=14)$ & $10.6 \%$ \\
\hline $\mathrm{B}(n=56)$ & $42.4 \%$ \\
\hline$C(n=52)$ & $39.4 \%$ \\
\hline $\mathrm{D}(n=10)$ & $7.6 \%$ \\
\hline \multicolumn{2}{|l|}{ Child-Pugh } \\
\hline $\mathrm{A}(n=81)$ & $61.4 \%$ \\
\hline $\mathrm{B}(n=38)$ & $28.8 \%$ \\
\hline$C(n=13)$ & $9.8 \%$ \\
\hline \multicolumn{2}{|l|}{ Number of nodules } \\
\hline Singular $(n=69)$ & $52.3 \%$ \\
\hline Multiple $(n=62)$ & $47 \%$ \\
\hline Diffuse $(n=1)$ & $0.7 \%$ \\
\hline \multicolumn{2}{|l|}{ Largest nodule size } \\
\hline$<20 \mathrm{~mm}(n=7)$ & $5.3 \%$ \\
\hline $20-<50 \mathrm{~mm}(n=15)$ & $11.4 \%$ \\
\hline $50-<100 \mathrm{~mm}(n=39)$ & $29.5 \%$ \\
\hline$\geq 100 \mathrm{~mm}(n=71)$ & $53.8 \%$ \\
\hline \multicolumn{2}{|l|}{ Metastasis } \\
\hline No $(n=115)$ & $87.1 \%$ \\
\hline Yes $(n=17)$ & $12.9 \%$ \\
\hline \multicolumn{2}{|l|}{ Portal vein thrombosis } \\
\hline No $(n=90)$ & $68.2 \%$ \\
\hline Yes $(n=42)$ & $31.8 \%$ \\
\hline
\end{tabular}

their research on 805 patients with Asian ethnicity, the cut-off of $10 \mathrm{ng} / \mathrm{ml}$ would result in the sensitivity and specificity of 82.6 and $70.4 \%$, respectively. This cut-off is preferable in the setting of surveillance as higher sensitivity is yielded much more of importance. 


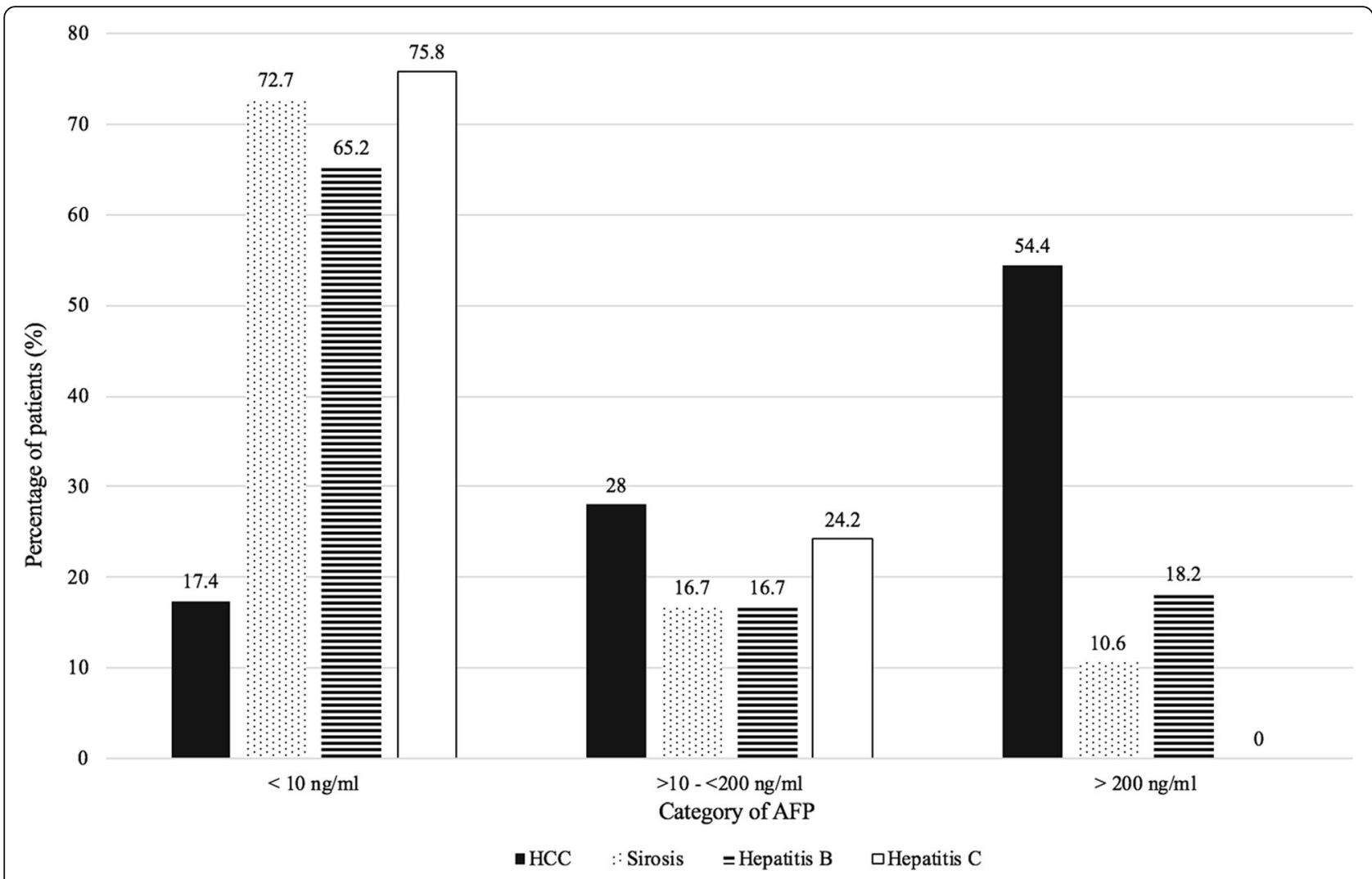

Fig. 2 AFP distribution in HCC patients and controls. HCC patients are portrayed with the colour of black and controls (population at risk in developing HCC) which include cirrhosis, hepatitis B and hepatitis C are depicted with dots, horizontal lines and solid white, respectively

In our study, we found the sensitivity, specificity, positive predictive value, negative predictive value, and likelihood ratio for positive test results of AFP in the surveillance of HCC of AFP (with a cut-off of $10 \mathrm{ng} / \mathrm{ml}$ ) was $82.6,71.2,65.6,85.9 \%$ and 2.87 , respectively. Interestingly, this result was in accordance with that of a study conducted in a population of 805 patients of Asian ethnicity by Chan SL, et al. [19], showing the AFP sensitivity and specificity values of $82.6 \%$ with a specificity of $70.4 \%$ (with a similar cut-off of $10 \mathrm{ng} / \mathrm{ml}$ ), with the results of positive predictive values and negative predictive values obtained as 86.6 and $63.6 \%$, respectively. On the other hand, research conducted by Biselli, et al. [20] in a population of HCC patients in Italy showed an AFP sensitivity with a cut-off of $10 \mathrm{ng} / \mathrm{ml}$ was $66.3 \%$ with a specificity of $80.6 \%$. It should be of note that the study conducted by Chan SL [19] in Asian patients had higher

Table 2 Sensitivity and specificity table of AFP test in the surveillance of HCC

\begin{tabular}{lll}
\hline AFP & HCC $(+)$ & HCC (-) \\
\hline AFP $\geq 10 \mathrm{ng} / \mathrm{ml}$ & 109 & 57 \\
& True Positive (TP) & False Positive (FP) \\
AFP $<10 \mathrm{ng} / \mathrm{ml}$ & 23 & 141 \\
& False Negative (FN) & True Negative (TN) \\
&
\end{tabular}

sensitivity levels than that conducted by Biselli, et al. [20] Sensitivity of the AFP test in Asian countries, predominantly in developing countries such as in Indonesia, is believed to be higher because the prevalence of HCC with the etiology of hepatitis B tends to be higher-presumably due to the lower coverage of hepatitis $B$ immunization in newborns [21].

We concluded that with a sensitivity of $82.6 \%$ and a specificity of $71.2 \%$, HCC surveillance using AFP test with a cut-off of $10 \mathrm{ng} / \mathrm{ml}$ is still useful due to its high sensitivity-as sensitivity levels above $80 \%$ still appear to be adequate for screening programs. High specificity, on the other hand, is more useful in establishing a diagnosis, so the specificity of $71.2 \%$ is still considered sufficient in the HCC surveillance program. That being said, we still recommend the use of AFP test to also be carried out along with USG to reach a higher sensitivity and specificity level in HCC surveillance. However, it should be noted that adding AFP into the screening algorithm will most likely increase the need for CT and MRI scans to confirm the positivity of the AFP findings, as the number of false-positive was $34 \%$ in this study.

In our study, it was found that etiology was one of the factors that were statistically significant $(p=0.011)$ in its probability to cause AFP levels of HCC patients to rise 
Table 3 Bivariate analysis

\begin{tabular}{|c|c|c|c|}
\hline \multirow[t]{2}{*}{ Variables } & \multicolumn{2}{|c|}{ Serum AFP: Number of Patients (\%) } & \multirow[t]{2}{*}{$P$} \\
\hline & $<10 \mathrm{ng} / \mathrm{ml}$ & $\geq 10 \mathrm{ng} / \mathrm{ml}$ & \\
\hline \multicolumn{4}{|l|}{ Etiology } \\
\hline Hepatitis B & 10 & 74 & \multirow[t]{4}{*}{0.011} \\
\hline Hepatitis C & 3 & 19 & \\
\hline Non-Hep B and C & 8 & 10 & \\
\hline Hepatitis B and C & 2 & 6 & \\
\hline \multicolumn{4}{|l|}{ Age (years) } \\
\hline$<40$ & 3 & 9 & \multirow[t]{3}{*}{0.7} \\
\hline $40-<50$ & 11 & 60 & \\
\hline$\geq 50$ & 9 & 40 & \\
\hline \multicolumn{4}{|l|}{ Sex } \\
\hline Female & 9 & 29 & \multirow[t]{2}{*}{0.34} \\
\hline Male & 14 & 80 & \\
\hline \multicolumn{4}{|l|}{ Size of nodule } \\
\hline$<20 \mathrm{~mm}$ & 3 & 4 & \multirow[t]{4}{*}{0.401} \\
\hline $20-<50 \mathrm{~mm}$ & 2 & 13 & \\
\hline $50-<100 \mathrm{~mm}$ & 7 & 32 & \\
\hline$\geq 100$ & 11 & 60 & \\
\hline \multicolumn{4}{|l|}{ Nodules } \\
\hline Singular & 15 & 54 & \multirow[t]{3}{*}{0.166} \\
\hline Multiple & 8 & 54 & \\
\hline Diffuse & 0 & 1 & \\
\hline \multicolumn{4}{|l|}{ Cirrhosis } \\
\hline None & 16 & 43 & \multirow[t]{2}{*}{0.016} \\
\hline Yes & 7 & 66 & \\
\hline \multicolumn{4}{|l|}{ Child-Pugh } \\
\hline Class A & 17 & 64 & \multirow[t]{3}{*}{0.36} \\
\hline Class B & 4 & 34 & \\
\hline Class C & 2 & 11 & \\
\hline \multicolumn{4}{|l|}{ Thrombus } \\
\hline None & 19 & 71 & \multirow[t]{2}{*}{0.165} \\
\hline Yes & 4 & 38 & \\
\hline \multicolumn{4}{|l|}{ Metastasis } \\
\hline None & 20 & 95 & \multirow[t]{2}{*}{0.97} \\
\hline Yes & 3 & 14 & \\
\hline \multicolumn{4}{|l|}{$\mathrm{BCLC}$} \\
\hline A & 5 & 9 & \multirow[t]{4}{*}{0.098} \\
\hline B & 11 & 45 & \\
\hline$C$ & 4 & 48 & \\
\hline D & 3 & 7 & \\
\hline
\end{tabular}

above $10 \mathrm{ng} / \mathrm{ml}$. It can be seen from Table 1 that the highest aetiological prevalence of $\mathrm{HCC}$ in the patient population in this study was hepatitis B, which was followed by hepatitis $\mathrm{C}$, and this is as per the current
Table 4 Multivariate Analysis

\begin{tabular}{lllll}
\hline & & & \multicolumn{2}{c}{$95 \% \mathrm{Cl}$} \\
\cline { 5 - 6 } & $p$ & OR & Lower & Upper \\
\hline BCLC C & .002 & 16.024 & 1.309 & 14.236 \\
Etiology of hepatitis B & .005 & 6.350 & 1.334 & 26.900 \\
Cirrhosis & .016 & 4.317 & 2.821 & 91.009 \\
BCLC B & .019 & 5.991 & 1.753 & 23.005 \\
\hline
\end{tabular}

data that shows that there are 400 million patients infected with HBV, 75\% of whom are Asian [22]. This significant result is also similar to that of a study conducted by Murugavel KG, et al. [23] which explained that there was a higher proportion of AFP elevation in HCC patients with the etiology of hepatitis B compared with other viral etiologies. Similar to the study conducted by Liu C, et al. [24], this study showed an increase of AFP level in cases of HCC caused by HBV compared with non-hepatitis cases of HCC. Also, a study conducted by Hann, et al. [25] showed that an increase in serum AFP in hepatitis B is in line with an increased risk for HCC.

We found that in HCC patients with the etiology of hepatitis B, $88.1 \%$ of patients had an increased level of AFP above $10 \mathrm{ng} / \mathrm{ml}$ cut-off with an odds ratio (OR) of 5.92 , which was statistically significant $(p=0.019)$. According to Li M, et al. [26], this tendency of an elevated AFP level in HBV-infected patients was due to the presence of HBV protein $(\mathrm{HBx})$ which could induce AFP receptor regulation, thereby increasing AFP expression in HCC due to HBV infection. Research conducted by Zhang C, et al. [27] and Yao M, et al. [28] also showed that HBV co-transcription factors could directly bind to AFP gene promoters, hence increasing its expression.

In the population of HCC patients with hepatitis C etiology, higher levels of AFP (above cut-off) was also found (with the OR 5.067) compared with the population of non-hepatitis HCC patients, although this OR was not statistically significant. Studies show that a significant increase in AFP was less common in patients with HCC with hepatitis C etiology [29, 30]. Studies conducted in Egypt, the country known to have the highest prevalence of hepatitis $\mathrm{C}$, showed that the prevalence of an increase in AFP levels above $10 \mathrm{ng} / \mathrm{ml}$ in HCC patients with etiology of hepatitis $\mathrm{C}$ was proven to be less frequent, occurring only in $11.6 \%$ patients [31]. These results were similar to those of research conducted in western countries with a higher prevalence of hepatitis $\mathrm{C}$ compared to hepatitis $\mathrm{B}$, wherein AFP elevation above cut-off occurred only in 10-43\% patients [32-34].

This study also showed a statistically significant difference in the proportion of HCC patients with cirrhosis and non-cirrhosis, when compared with AFP levels above and below $10 \mathrm{ng} / \mathrm{ml}(p=0.016)$. There were $55.3 \%$ 
$(n=73)$ patients with cirrhosis in this study. We also found that HCC patients with cirrhosis would have a higher risk of having an elevated AFP level above cut-off (OR $3.508, p=0.011$ ). These results were similar to those of previous studies, as cirrhosis is one of the main known risk factors for HCC, and is found in $80-90 \%$ of all HCC cases. $\mathrm{HCC}$ is also one of the causes of death in patients with cirrhosis of the liver, with the rate of developing HCC in patients with liver cirrhosis per year being $5 \%[35,36]$. This causes all patients with cirrhosis with any etiology to be recommended through surveillance of HCC [36, 37]. Pathological study has shown that patients with chronic liver disease can express AFP without prior development of HCC [38]. The study by Harada T, et al. [39] showed that approximately $40 \%$ of all cirrhotic patients will have AFP levels higher than $20 \mathrm{ng} / \mathrm{ml}$. An increase in AFP levels (between 10 and $500 \mathrm{ng} / \mathrm{ml}$, and sometimes up to $1000 \mathrm{ng} / \mathrm{ml}$ ) can be seen in adult patients with hepatitis or cirrhosis with any etiology. Also, the frequency of elevated AFP levels (> $10 \mathrm{ng} / \mathrm{mL}$ ) was reported in $20 \%$ of cases of chronic hepatitis and $40 \%$ of cases of cirrhosis [40].

This study also found that BCLC stage $\mathrm{C}(p=0.002)$, etiology of hepatitis $\mathrm{B}(p=0.005)$, cirrhosis $(p=0.016)$ and BCLC B stage $(p=0.019)$ were all independent predictors of elevated AFP levels above $10 \mathrm{ng} / \mathrm{ml}$. The BCLC C classification, which was considered an advanced stage, classified patients who had already developed tumours invading the portal vein and those who had already developed extrahepatic dissemination. The condition of the spread of these tumours, according to literature [41], was related to higher AFP levels, although this was not statistically proven in this study. However, it should be taken into account that detecting the increase AFP level in the earlier stages is paramount. In our study, there were 14 (10,6\%) BCLC stage A HCC patients, whom $9(64,2 \%)$ were found to have an increase AFP level (Table 3). This emphasizes the advantage of using AFP as a surveillance tool even within the earlier stages. However, further investigation of the diagnostic accuracy in the earlier stage would require a more adequate number of subjects and is an interesting study that should be conducted. In our setting, as most of HCC patients were already in advance stages and the included HCC population in this study was all ultrasound positive, the additive value of AFP may seem unclear. Nevertheless, Singal et al. [42] stated if ultrasound was the only method of surveillance used in detecting HCC, the sensitivity will only reach $58 \%$, whereas when combined with AFP, the sensitivity will increase to $87 \%$. Questions regarding the additive value of AFP if compared to ultrasound only is intriguing-and further study should be conducted.

\section{Conclusion}

The sensitivity level of $82.6 \%$ and specificity level of $71.2 \%$ in the surveillance of HCC using AFP with a cut- off of $10 \mathrm{ng} / \mathrm{ml}$ are considered useful in Indonesia. The multivariate analysis showed the factors most associated with an increase in AFP levels above $10 \mathrm{ng} / \mathrm{ml}$ were BCLC C $(p=0.002)$, the etiology of hepatitis B $(p=$ $0.005)$, cirrhosis $(p=0.016)$ and BCLC B $(p=0.019)$.

\section{Abbreviations \\ HCC: Hepatocellular carcinoma; AFP: a-fetoprotein; RSCM: Cipto Mangunkusumo National General Hospital, Jakarta; RSKD: Dharmais National Cancer Hospital, Jakarta; MRI: Magnetic resonance imaging; HBV: Hepatitis B virus; HCV: Hepatitis C virus; BCLC: Barcelona Clinic Liver Cancer; OR: Odds ratio; HBx: HBV protein}

\section{Acknowledgements}

This study did not receive any grant supports. The authors would like to thank Gita Aprilicia and Dr. Rahmanandhika Swadari who provided commendable assistance in this study. We would also like to thank Dr. Dewi Friska from the Department of Community Medicine, Faculty of Medicine, Universitas Indonesia for all the support from the beginning until the completion of this study.

\section{Conflict of interests}

Declaration of potential conflict of interest: This study did not receive any grant. There is no conflict of interest in this study.

\section{Authors' contributions}

AF proposed and conducted the study, CMJ performed the research and supervised the research and also gave the idea for the first draft of the manuscript, LS and IL collected and analysed the data. All authors contributed in designing the study, interpreting results, and writing the final manuscript. CMJ is the guarantor. The author(s) read and approved the final manuscript.

\section{Funding}

There's no funding to declare.

\section{Availability of data and materials}

The datasets used in the study are available from the corresponding author upon reasonable request.

\section{Ethics approval and consent to participate}

All procedures performed involving human participants were in accordance with the ethical standards of the institutional and/or national research committee and with the 1964 Helsinki declaration and its later amendments or comparable ethical standards.

This study has been approved by the Institutional Review Board (Medical Faculty Universitas Indonesia Ethical Committee) no. 0514/UN2.F1/ETIK/2018. Written informed consents were obtained from all patients.

\section{Consent for publication}

Not applicable.

\section{Competing interests}

The authors declare that they have no competing interests.

\section{Author details}

${ }^{1}$ Hepatobiliary Division, Department of Internal Medicine, Faculty of Medicine, Universitas Indonesia, Cipto Mangunkusumo National General Hospital, Jakarta, Indonesia. ${ }^{2}$ Faculty of Medicine, Universitas Indonesia, Cipto Mangunkusumo National General Hospital, Jakarta, Indonesia. ${ }^{3}$ Division of Gastroenterology and Hepatology, Department of Internal Medicine, Faculty of Medicine, Universitas Indonesia, Dharmais National Cancer Hospital, Jakarta, Indonesia.

Received: 10 February 2020 Accepted: 2 July 2020

Published online: 09 July 2020

\section{References}

1. Llovet J, Zucman-Rossi J, Pikarsky E, Sangro B, Schwartz M, Sherman M, et al. Hepatocellular carcinoma. Nat Rev Dis Primers. 2016;2:16018. 
2. Park JW, Chen M, Colombo M, Roberts LR, Schwartz M, Chen PJ, et al. Global patterns of hepatocellular carcinoma management from diagnosis to death: the BRIDGE study. Liver Int. 2015;35:2155-66.

3. World Health Organization. Cancer country profiles. Indonesia national incidence estimates and modelled survival. 2014. Available from: http:// www.who.int/cancer/country-profiles/idn_en.pdf. (cited 29 April 2018).

4. Mulyana E. Analisis Kesintasan Pasien Hepatoma di RSUPN-CM Jakarta. [Tesis]. Jakarta: Departemen IImu Penyakit Dalam Fakultas Kedokteran Universitas Indonesia; 2001.

5. El-Serag HB, Marrero JA, Rudolph L, Reddy KR. Diagnosis and treatment of hepatocellular carcinoma. Gastroenterology. 2008;134:1752-63.

6. Song P, Tobe RG, Inagaki Y, Kokudo N, Hasegawa K, Sugawara Y, at al. The management of hepatocellular carcinoma around the world: a comparison of guidelines from 2001 to 2011. Liver Int 2012;32:1053-1063.

7. Lesmana LA, Waspodo AS, Gani RA, Hasan I, Siregar L, Sulaiman AS. Konsensus Nasional Penatalaksanaan Karsinoma Sel Hati. Jakarta: Perhimpunan Peneliti Hati Indonesia; 2017.

8. Asrih M, Lenglet S, Mach F, Montecucco F. Alpha-fetoprotein: a controversial prognostic biomarker for small hepatocellular carcinoma. World J Gastroenterol: WJG. 2013;19:328.

9. Song PP, Xia JF, Inagaki Y, Hasegawa K, Sakamoto Y, Kokudo N, Tang W. Controversies regarding and perspectives on clinical utility of biomarkers in hepatocellular carcinoma. World J Gastroenterol. 2016;22:262.

10. Bertino G, Neri S, Bruno CM, Ardiri AM, Calvagno GS, Malaguarnera M, et al. Diagnostic and prognostic value of alpha-fetoprotein, des- $\gamma$-carboxy prothrombin and squamous cell carcinoma antigen immunoglobulin $\mathrm{M}$ complexes in hepatocellular carcinoma. Minerva Med. 2011;102:363-71.

11. Gopal P, Yopp AC, Waljee AK, Chiang J, Nehra M, Kandunoori P, et al. Factors that affect accuracy of a-fetoprotein test in detection of hepatocellular carcinoma in patients with cirrhosis. Clin Gastroenterol Hepatol. 2014;12:870-7.

12. Di Carlo I, Mannino M, Toro A, Ardiri A, Galia A, Cappello G, et al. Persistent increase in alpha-fetoprotein level in a patient without underlying liver disease who underwent curative resection of hepatocellular carcinoma. A case report and review of the literature. World J Surg Oncol. 2012;10:79.

13. Bruix J, Sherman M. Management of hepatocellular carcinoma: an update. Hepatology. 2011;53:1020-2.

14. European Association For The Study Of The Liver. EASL-EORTC clinical practice guidelines: management of hepatocellular carcinoma. J Hepatol. 2012;56:908-43.

15. Omata M, Lesmana LA, Tateishi R, Chen PJ, Lin SM, Yoshida H, et al. Asian Pacific Association for the Study of the liver consensus recommendations on hepatocellular carcinoma. Hepatol Int. 2010;4:439-74.

16. Xie DY, Ren ZG, Zhou J, Fan J, Gao Q. Critical appraisal of Chinese 2017 guideline on the management of hepatocellular carcinoma. Hepatobiliary Surg Nutr. 2017;6:387.

17. Kokudo N, Hasegawa K, Akahane M, Igaki H, Izumi N, Ichida T, et al. Evidencebased clinical practice guidelines for hepatocellular carcinoma: the Japan society of hepatology 2013 update (3rd JSH-HCC guidelines). Hepatol Res. 2015;45.

18. Trevisani F, D'Intino PE, Morselli-Labate AM, et al. Serum alpha-fetoprotein for diagnosis of hepatocellular carcinoma in patients with chronic liver disease: influence of HBsAg and anti-HCV status. J Hepatol. 2001;34:570-5.

19. Chan SL, Mo F, Johnson PJ, Siu DY, Chan MH, Lau WY, et al. Performance of serum a-fetoprotein levels in the diagnosis of hepatocellular carcinoma in patients with a hepatic mass. HPB. 2014;16:366-72.

20. Biselli M, Conti F, Gramenzi A, Frigerio M, Cucchetti A, Fatti G, et al. A new approach to the use of a-fetoprotein as surveillance test for hepatocellular carcinoma in patients with cirrhosis. Br J Cancer. 2015;112:69.

21. Kew MC. Hepatocellular carcinoma in developing countries: prevention, diagnosis and treatment. World J Hepatol. 2012;4:99.

22. Gust ID. Epidemiology of hepatitis B infection in the Western Pacific and South East Asia. Gut. 1996;38:S18-23.

23. Murugavel KG, Mathews S, Jayanthi V, Shankar EM, Hari R, Surendran R, et al. Alpha-fetoprotein as a tumor marker in hepatocellular carcinoma: investigations in south Indian subjects with hepatotropic virus and aflatoxin etiologies. Int J Infect Dis. 2008;12:e71-6.

24. Liu C, Xiao GQ, Yan LN, Li B, Jiang L, Wen TF, et al. Value of a-fetoprotein in association with clinicopathological features of hepatocellular carcinoma. World J Gastroenterol: WJG. 2013;19:1811.

25. Hann HW, Fu X, Myers RE, Hann RS, Wan S, Kim SH, et al. Predictive value of alpha-fetoprotein in the long-term risk of developing hepatocellular carcinoma in patients with hepatitis B virus infection-results from a clinicbased longitudinal cohort. Eur J Cancer. 2012;48:2319-27.

26. Li M, Zhu M, Li W, Lu Y, Xie X, Wu Y, et al. Alpha-fetoprotein receptor as an early indicator of HBxdriven hepatocarcinogenesis and its applications in tracing cancer cell metastasis. Cancer Lett. 2013;330:170-80.

27. Zhang C, Chen X, Liu H, Li H, Jiang W, Hou W, et al. Alpha fetoprotein mediates HBx induced carcinogenesis in the hepatocyte cytoplasm. Int J Cancer. 2015;137:1818-29. https://doi.org/10.1002/ijc.29548.

28. Yao M, Zhao J, Lu F. Alpha-fetoprotein still is a valuable diagnostic and prognosis predicting biomarker in hepatitis B virus infection-related hepatocellular carcinoma. Oncotarget. 2016;7:3702

29. Furui J, Furukawa M, Kanematsu T. The low positive rate of serum alphafetoprotein levels in hepatitis C virus antibody-positive patients with hepatocellular carcinoma. Hepatogastroenterology. 1995;42:445-9.

30. Peng YC, Chan CS, Chen GH. The effectiveness of serum alpha-fetoprotein level in anti-HCV positive patients for screening hepatocellular carcinoma. Hepato-gastroenterology. 1999;46:3208-11.

31. Kobeisy MA, Morsy KH, Galal M, Sayed SK, Ashmawy MM, Mohammad FM. Clinical significance of elevated alpha-foetoprotein (AFP) in patients with chronic hepatitis $C$ without hepatocellular carcinoma in upper EGYPT. Arab J Gastroenterol. 2012;13:49-53.

32. Fattovich G, Giustina G, Degos F, Tremolada F, Diodati G, Almasio P, et al. Morbidity and mortality in compensated cirrhosis type $\mathrm{C}$ : a retrospective follow-up study of 384 patients. Gastroenterology. 1997;112:463-72.

33. Sato Y, Nakata K, Kato Y, Shima M, Ishii N, Koji T, et al. Early recognition of hepatocellular carcinoma based on altered profiles of alpha-fetoprotein. $\mathrm{N}$ Engl J Med. 1993;328:1802-6.

34. Tong MJ, El Farra NS, Reikes AR, Co RL. Clinical outcomes after transfusionassociated hepatitis C. N Engl J Med. 1995;332:1463-6.

35. Aguayo A, Patt YZ. Liver cancer. Clin Liver Dis. 2001;5:479-508.

36. Chang TS, Wu YC, Tung SY, Wei KL, Hsieh YY, Huang HC, et al. Alphafetoprotein measurement benefits hepatocellular carcinoma surveillance in patients with cirrhosis. Am J Gastroenterol. 2015;110:836.

37. Singal A, Volk ML, Waljee A, Salgia R, Higgins $P$, Rogers MA, et al. Metaanalysis: surveillance with ultrasound for early-stage hepatocellular carcinoma in patients with cirrhosis. Aliment Pharm Ther. 2009;30:37-47.

38. Grizzi F, Colombo P, Taverna G, Chiriva-Internati M, Cobos E, Graziotti P, et al. Geometry of human vascular system: is it an obstacle for quantifying antiangiogenic therapies? Appl Immunohisto M M. 2007;15:134-9.

39. Harada T, Shigeta K, Noda K, Fukumoto Y, Nishimura H, Mizuta M, et al. Clinical implications of alpha-fetoprotein in liver cirrhosis: five-year follow-up study. Hepato-gastroenterology. 1980;27:169-75.

40. Johnson PJ. The role of serum alpha-fetoprotein estimation in the diagnosis and management of hepatocellular carcinoma. Clin Liver Dis. 2001;5:145-59.

41. Lu Y, Zhu M, Li W, Lin B, Dong X, Chen Y, Xie X, Guo J, Li M. Alpha fetoprotein plays a critical role in promoting metastasis of hepatocellular carcinoma cells. J Cell Mol Med. 2016;20:549-58.

42. Singal AG, Conjeevaram HS, Volk ML, Fu S, Fontana RJ, Askari F, et al. Effectiveness of hepatocellular carcinoma surveillance in patients with cirrhosis. Cancer Epidemiol Biomark Prev. 2012;21(5):793-9.

\section{Publisher's Note}

Springer Nature remains neutral with regard to jurisdictional claims in published maps and institutional affiliations.

\section{Ready to submit your research? Choose BMC and benefit from:}

- fast, convenient online submission

- thorough peer review by experienced researchers in your field

- rapid publication on acceptance

- support for research data, including large and complex data types

- gold Open Access which fosters wider collaboration and increased citations

- maximum visibility for your research: over $100 \mathrm{M}$ website views per year

At BMC, research is always in progress.

Learn more biomedcentral.com/submissions 